\title{
Sustainability and Depletion Accounting: A Case Study of Oil in Libya
}

\author{
Abdulrazag Mohamed Etelawi ${ }^{1}$, Keith A. Blatner ${ }^{2} \&$ Jill McCluskey $^{3}$ \\ ${ }^{1}$ Department of Mathematics and Statistics, Washington State University, Pullman, WA, USA \\ ${ }^{2}$ School of the Environment, Washington State University, Pullman, WA, USA \\ ${ }^{3}$ School of Economic Sciences, Washington State University, Pullman, WA, USA \\ Correspondence: Keith A. Blatner, School of the Environment, Washington State University, Pullman, WA, USA. \\ Email: blatner@wsu.edu
}

Received: December 23, 2016

Accepted: January 9, 2017

Online Published: February 3, 2017

doi:10.5539/enrr.v7n1p34

URL: http://dx.doi.org/10.5539/enrr.v7n1p34

\begin{abstract}
There is a strong need to study sustainability and depletion accounting of oil in the Libyan economy because oil production and export is the single largest source of national income in the country. This study covers the time period from 1990 to 2009. Throughout this period, the Libyan national economy used its oil and petroleum industries to increase national income. Development sustainability can be defined as investment divided by GDP. This measure provides an indication of the low level of sustainable development in Libya over the period of analysis, which is 0.38 on average. It is important that the Libyan government develop and implement plans and strategies for achieving sustainability and the maintenance of oil resources.

Carbon dioxide emissions provide another indication of the presence or absence of sustainability. The ratio of carbon dioxide ranged from a minimum of 8.50 metric tons per capita in 1990 to 10.00 metric tons per capita in 2009 and average 9.07 metric tons per capita over the course of the study period. $\mathrm{CO}_{2}$ emissions were also much higher than other countries in the Middle East and North Africa. This suggests there was relatively little interest in the sustainable development of the Libyan economy during this period. The Environment Domestic Product (EDP) increased sharply from the beginning of the study at $\$ 24.23$ billion in 1991 to $\$ 45.87$ billion in 2009 in constant dollars. Again, one can infer that policy makers did not consider the depletion of oil resources and the environment in their planning process, or at least did not place a high level of concern on this issue.
\end{abstract}

Keywords: Libya economy, sustainability, depletion

\section{Introduction}

Developing countries have utilized their natural resources to improve their economies for decades. In turn, it is important for these countries to use their resources in ways that promote sustainable development. Without plans and strategies for improving of their economy, the eventual depletion of the resource will lead to other problems, such as increased unemployment, loss of potential economic benefits to future generations, and potential political issues.

The Libyan economy is heavily dependent upon the oil sector. Oil represents about 95 percent of all exports, about 99 percent of Libyan government income, and approximately 80 percent of GDP (CIA, 2013). Depletion of the oil resource without alternative economic development would have a disastrous effect on future generations (CIA, 2013).

Libya declared its independence from France in 1951. At that time Libya was described as one of the poorest countries in the world. Libya lacked infrastructure for health care, electricity, education, and was dependent on older agricultural methods (Wallace \& Wilkin, 2004). The Libyan economy rose to a new level with the drilling of the first successful oil well in 1956. The first oil was exported in 1961 (EIA, 1984).

The Libyan economy has been dependent on oil for over 40 years. Unfortunately, no significant investment of oil revenues in the economy occurred during this period, due to the political situation in the country. During this period the Libyan government sold oil and purchased other commodities with little consideration given to economic development or sustainability. 
The Libyan economy also exhibits a high level of corruption as evidenced by its score of 21 out of 100 on Transparency International's Corruption Perceptions Index during this period. A country's score provides an indication of the perceived level of public sector corruption on a scale of $0-100$ (Transparency International, 2012). Both of Libya's neighbors have public sectors that are perceived as less corrupt: Egypt has a score of 32 and Tunisia has a score of 41 . For comparison, Somalia, received the lowest score in the world with a score of eight.

This research assesses those factors that contribute to the longevity of the oil-based economy of Libya, which in turn, could lead to the growth of the overall economy. The investment of the wealth derived from oil could lead to an improvement in the standard of living for the people of Libya; creating more jobs and increasing the level of economic activity in the entire economy.

\section{Literature Review}

Sustainability is the pattern of using available resources to meet human needs, while maintaining an environment not only for today but also for the future (United Nations, 1987). Schneider, Campbell, Vargo, C, and Hall (2011) states that sustainability refers to creating a balance between the supply and demand of a non-renewable resource for achieving a triangle of goals: environmental, economic, and social.

The oil industry is the only sector in Libya that is in a position to provide large returns to the economy, but that alone does not guarantee sustainability. Prugh, Costanza, and Daly (2000) demonstrate that it is difficult to determine a minimum requirement for sustainability, because it depends on different factors such as available resources and consumption requirements. Further, the amount of oil consumed increases as population increases, which makes the implementation of specific policies designed to enhance sustainability difficult to achieve.

Kasemir, Jager, Jaeger, Carlo, and Gardener. (2003) conclude that sustainability is a complex dynamic combination of economic, environmental and social issues. Moreover, the authors emphasize that there is a need to increase "public participation in its discussion and debates" (p. 3) in order to develop specific strategies and methods in order to achieve sustainability. How humans deal with the environment and the natural world is very important in achieving sustainability and limiting the depletion of natural resources.

Goldin and Winters (1995) demonstrate that sustainable development refers to development, which has met the requirement of creating a balance between the current and future generations. They also typically use the term "steady state" in the economic sciences, instead of the term "needs for the sustainability." There are a number of issues related to the concept of sustainability such as the "growth controversy." The growth controversy argues that the natural world has achieved its maximum level of growth and that further growth will lead the world away from sustainability. Moreover, the authors emphasize that sustainable growth is required for development sustainability. Another argument related to sustainability refers to the pollution produced by people living under severe poverty, which in turn leads to a further reduction in sustainability.

Peet (1992) explains the difference between sustainable growth and sustainable development. Sustainable development has to be natural, normal, and wanted, but sustainable growth is impossible, and can be self-contradictory. It is easy to be confused between these terms, because of quality and quantity. The author also defines sustainability as “... not something to be defined, but to be declared. It is an ethical guiding principle," (p. 209). The author further argues that there are two types of sustainability: strong and weak sustainability. Strong sustainability focuses on natural capital and human made capital, while weak sustainability focuses on the substitution of human capital for natural resource based capital.

Berke \& Conory (2000) illustrate that sustainable development is "development that meets the needs of the present generation without compromising the ability of future generations to meet their own needs" (p. 22). The authors explain that there are different characteristics that one may use to define sustainable development: reproduction, balance, links between local and global concerns, and dynamic processes. Sustainable development may be defined as "the long-term ability of a system to produce" (p. 22). The first characteristic is reproduction, which includes a duplication of the current situation and development. The second characteristic is the balance among the economy, social values, and the environment. The third characteristic of sustainable development demands that societies move beyond their different interests in accounting for local and global needs in future development. The fourth characteristic is the dynamic process of sustainability, in which societies allow citizens to participate in different economic activities. The authors emphasize that there is no specific agreement among definitions that define development sustainability.

Cooper and Vargas (2008) also argue that sustainability refers to creating a balance between environmental, social and economic development. Sustainable development focuses on the long-term future, not the short-term period of immediate economic needs; political stability and natural resource security may require achieving the 
development of sustainability. Cavagnaro and Curie (2012) demonstrate that oil sustainability is important and improves the life of the people, because it results in a higher quality of life through the consideration of social, environmental, and economic factors.

Oil spills are important factors that directly affect sustainability and the depletion of oil resources. Obviously, when oil spills increase; the sustainability of oil resources decreases due to the loss of oil. Eljabri and Gallagher (2012) illustrate that oil spills are one of the main sources of environmental pollution. Oil spills also result in a direct economic loss to the economy. The authors emphasize " $\ldots$ in the last decade there has been a growing concern over the increasing contamination and adjacent shoreline areas [affected] by oil spills" (p.17). These spills negatively affect sustainability and increase oil depletion. There are many underlying causes for oil spills. Al-Majed, Adebayo, and Hossain (2012) explain that there are different factors, which could effectively control oil spills. They also suggest using advanced technology for decreasing or stopping oil spills in order to maintain oil resources for future generations. Thus, using advanced technology and information resources such as geographic information systems (GIS), daily or monthly pipeline maintenance and oil flow rates within pipelines are very important to preventing spills and improving oil sustainability.

Naimi (2011) argues there are different approaches which may be used to enhance the sustainability of the petroleum industry. The author found that multiple approaches are required to achieve the various goals of sustainability. Her work focused on using local mechanisms adopted internally by the Shell Oil Company.

Weaver (2003) concludes that sustainable development refers to the triple bottom line, which includes economic, environmental and social progress. Weaver argues that involving the Multinational Corporations (MNCs) can increase the opportunities for achieving high levels of environmental and social factors as well as sustainable development.

It is important for industrial companies to utilize high levels of technology, skills and experience in order to achieve a cleaner oil industry. This expertise allows production of a quality product with a minimum of economic, social, and environmental problems. Governments often use of two major approaches to encourage firms to decrease environmental pollution. These include: increasing taxes on various production units and decreasing subsidies for these firms.

Thompson (2012) explains that adding non-renewable resources to the neoclassical growth model, including labor and capital, could lead to the achievement of improved economic growth and income distribution -- a rising resource price implies optimal depletion. Resource productivity (or resource efficiency) and depletion are increased through investment and labor growth. Moreover, the author emphasizes depletion may increase with a rising wage, when the resource is a substitute for labor.

Ali (2009) illustrates that the oil industry plays a major role in the economy of oil producing countries. When a country is heavily dependent on oil for national income, it can lead to depletion of the oil resource. In turn, depletion may increase the cost of the resource and the use of advanced technology for extracting oil in difficult areas. Depletion of the oil resource may also lead to increased concerns by the government about future generations, the environment and the economy.

Bardi (2005) demonstrates that depletion of mineral resources and production of oil "has been an object of extensive predictive modeling" (p.53). The author explains that modern oil supply predictions are usually developed using Hubbert's model (Hubbert, 1962). Bardi (2005) also illustrates that Hubbert's model depends on the "fitting of the experimental data to a symmetric, bell-shaped curve." Hubbert's model does not apply to all mineral economies because sharp declines in production can make the production curve asymmetric. There are different ways to predict the depletion of non-renewable resources; however, it should be pointed out that there is no exact method due to a wide variety of factors including technological change. Conversely, improved estimation of production could help balance the use of the resource between current and future generations.

Prior, Giurco, Mudd, Mason, and Behrisc (2007) posits that the world relies heavily on mineral and other non-renewal resources, and the consumption of these resources requires increased production in low, middle, and high income countries. The authors also mention that oil is a non-renewable resource and the speed of the development could be finite. Mikesell (1997) further notes that the relationship between the economic growth and natural resources has been the opposite in his study in developing countries and there is no specific reason for that relationship, but it likely relates to sustainability issues.

\section{Theory and Model}

According to the World Bank (2015), energy depletion can be defined as the value of the stock of energy resources divided by the remaining lifetime of the reserve supply. This relationship applies to crude oil, gas, and coal as well 
as mineral resources such as iron, zinc, lead, gold, nickel, phosphate, bauxite, and silver. Thus, it is possible to apply the same model for accounting for crude oil depletion. Since both of them have a limited reserve and they do not increase in supply quickly.

Santopietro (1998) explains that the theory behind natural resources and depletion can be determined using production and depletion costs. How to manage the depletion of a natural resource and the production of this resource is the main point of the theory. Since the natural resource in question is very difficult or impossible to replenish; it is necessary to have an effective plan to achieve economic sustainability.

Auty and Mikesell (1998) illustrate that there are several ways to calculate resource depletion including: the U.S. Department of Commerce Method, the Present-Value Method, the World Bank Method, the Net Price Method (Repetto, Magrath, Wells, \& Rossini, 1989), and the User-Cost (El Serafy - United Nations, 1989) Method. Naturally, accounting for natural resource depletion and sustainability should focus on the economic benefits for the country.

The Net Price Method or the World Bank Method was chosen, because the data are readily available and easy to calculate for both methods. Green and Blatner (2015) explain that the Net Price Method is often used, because of the flexibility within the range of estimates in determining adjustments to GDP. This does not mean other methods are not as effective, they are just more difficult to apply.

\section{The Net Price Method}

Auty \& Mikesell (1998) suggest that the net price method is similar to Hotelling's (1931) model, except net price is calculated by subtracting the current price from the average extraction cost, covering estimation of normal profit on capital investment. They defined resource depletion as the net in storage of natural resource multiplied by the net price, where the net in storage of natural resource can be calculated by extraction minus the ratio of the increase in estimated reserves. The formula for accounting for the depletion of the oil resource is equal to price minus average cost multiplied by depletion minus resource discoveries or $(\mathrm{P}-\mathrm{AC}) \mathrm{x}(\mathrm{R}-\mathrm{D})$.

Rubio (2004) emphasizes that the net price method reveals natural capital depreciation $\left(\delta_{\mathrm{N}} \mathrm{K}_{\mathrm{N}}\right)$ is consistent with resource rent $\left(\mathrm{N}_{\mathrm{t}}\right)$ for the year, where resource rent is estimated as the marginal profit multiplied by the quantity removed. Auty \& Mikesell (1998) argue that resource rent (net price) may be used to establish depletion and so income is not calculated due to the effort required to estimate mineral reserves outside of the capital investment return calculation. The authors also emphasize that it is not clear if this approach yields pure resource rent or includes a payment used for risk on capital investment.

Santopietro (1998) concludes that the net price method has been used for resource rent and depletion cost of Argentina's petroleum reserves. He indicates that it is an effective method, because it is uses a simple assumption to estimate the rent per unit ignoring the other assumptions required under the present value method. Repetto et al. (1998) also used the net price method for calculating the depreciation of oil reserves in Indonesia.

\section{World Bank Method}

Green \& Blatner (2015) explain that the World Bank method is similar to the net price method; however, it does not rely on the resource discoveries method. The World Bank restricts the price of carbon dioxide $\left(\mathrm{CO}_{2}\right)$ and calculates the environmental damage based on $\$ 20$ per metric ton of $\mathrm{CO}_{2}$. The formula of World Bank equals price minus average cost times depletion.

Neumayer (2000) argues that World Bank method is similar to the Hotelling's (1931) concept of rent, except that it uses average costs instead of marginal costs. Resource discoveries are ignored in this method because using average discoveries is a more available proxy for marginal costs. Since "exploration expenditures are treated as investment in standard national accounting already, there is no correction term for discoveries" (page 8).

The primary difference between the two methods is the calculation of the amount of crude oil discovered. The World Bank Method does not directly consider crude oil discoveries, while the net price method does. However, the difference is insignificant.

\section{Data}

Data for this study were obtained from a variety of sources including: the United Nations, World Bank, Organization Petroleum Export Countries (OPEC), Central Bank of Libya, and United States Energy Information Administration (EIA). Table 1 summarizes the key variables used in this paper. The data includes the Gross Domestic Product (GDP), Consumption of Fixed Assets (CFA), Net Domestic Product (NDP), Current Extraction (CE), Resource Depletion (RD), Deterioration Quality of Resources (DQR), and Environment Domestic Product (EDP). Tables 2 and 3 present the data used in this study. Table 2 presents GDP, CFA, NDP, oil reserves, and oil 
production (natural resource depletion). All currency based variables are expressed in current dollars. Table 3 presents the same variables in constant 2005 dollars.

Table 1. Keywords and their definitions used in the paper

\begin{tabular}{|c|c|c|}
\hline Abbreviation & Meaning & Definition and Formula \\
\hline GDP & Gross Domestic Product & $\begin{array}{l}\text { The total expenditure of personal } \\
\text { consumption, total local private investment, } \\
\text { public, and net export. }\end{array}$ \\
\hline CFA & Consumption of Fixed Assets & Depreciation of CFA \\
\hline NDP & Net Domestic Product & $\begin{array}{l}\text { Net domestic Product }=\text { Gross Domestic } \\
\text { Product minus Consumption Fixed Assets }\end{array}$ \\
\hline $\mathrm{CE}$ & Current Extraction & Partial extracted in years \\
\hline $\mathrm{RD}$ & Resource Depletion & $\begin{array}{l}\text { Market value of Resource Depletion that } \\
\text { reduced from the assets by different years. } \\
\text { Calculation can be done by different } \\
\text { methods, see preview pages. }\end{array}$ \\
\hline DQR & Deterioration Quality of Resources & Represents by $\mathrm{CO} 2$ emissions. \\
\hline EDP1 & Environment Domestic Product & $\mathrm{EDP} 1=\mathrm{GDP}-\mathrm{CFA}-\mathrm{RD}$-minor adjustment \\
\hline \multirow[t]{2}{*}{ Market Value of Depletion } & World Bank method & $(\mathrm{P}-\mathrm{AC}) * \mathrm{R}$ \\
\hline & Net price method & $(\mathrm{P}-\mathrm{AC}) *(\mathrm{R}-\mathrm{D})$ \\
\hline
\end{tabular}

GDP in current dollars increased from $\$ 31.09$ billion in 1990 to $\$ 81.38$ billion in 2008 for an average of $\$ 39.97$ billion dollars per year. The maximum value of consumption of fixed capital of $\$ 11.43$ billion occurred in 2008 , while the minimum value of $\$ 3.45$ billion occurred in 1990 .

The minimum NDP of $\$ 23.50$ billion occurred in 2002, while the maximum was $\$ 69.95$ billion in 2008 (current dollars). The NDP increased on average throughout the period of analysis rising to $\$ 34.43$ billion dollars. Oil production (natural resource depletion) increased from $\$ 6.29$ billion in 1989 to $\$ 59.39$ billion in 2008 (current dollars).

Table 3 summarizes production costs, oil revenue, exports, $\mathrm{CO}_{2}$ emissions, and environment domestic product. The lowest production cost of $\$ 2.49$ /barrel (current dollars) occurred in 1995, while the highest production cost was $\$ 7.31 /$ barrel in 2009. The average cost of oil production over the course of the study was $\$ 4.02 /$ barrel.

Carbon dioxide emissions provide an indication the Deterioration Quality of Resources. When the ratio of $\mathrm{CO}_{2}$ increases, it means that environmental quality has decreased, which in turn indicates a decrease in sustainable development. The minimum value of $\mathrm{CO}_{2}$ emissions was 8.3 metric tons per capita in 1992 . The maximum value of $\mathrm{CO}_{2}$ emissions was 10.0 metric tons capita in 2009. Carbon dioxide emissions from Libya are about twice that of other countries in the Middle East and North Africa in total (World Bank 2015).

Environment domestic production (EDP) increased from \$24.24 billion in 1990 to 45.87 billion (constant 2005) dollars in 2009. The average of environment domestic production was 34.08 billion dollars over the course of the study. It is important to note that the value of environment domestic product provides a measure of the cost to the environment.

Table 4 summarizes, proven crude oil reserves, sustainable development, market value of depletion using the World Bank method, and market value of depletion using the net price method. Proven crude oil reserves increased from 29.50 billion barrels for the period 2000-2004 to 46.42 billion barrels for 1990 and 2009. Oil return increased from $\$ 768.06$ million in 1993 to $\$ 66.27$ billion in 2008 in constant prices. Sustainable Development increased from 0.02 in 1993 to 1.51 in 2008 . The average annual increase for the study period was 0.37 (constant dollars). The market value of depletion (World Bank Method) increased from \$5.72 billion in 1994 to $\$ 46.24$ billion in 2008 , for an average of $\$ 15.06$ billion annually over the study period (constant dollars). The Market Value of Depletion (Net Price Approach) increased from -8.36E+11 billion dollars in 1990 to $-1.99 \mathrm{E}+12$ billion dollars in 2005 for an average of $-1.17 \mathrm{E}+12$ billion dollars annually. 
Table 2. Calculations for the first part of terms

\begin{tabular}{|c|c|c|c|c|c|c|c|c|c|c|c|c|}
\hline  &  &  & 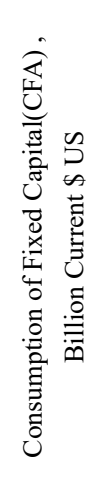 & 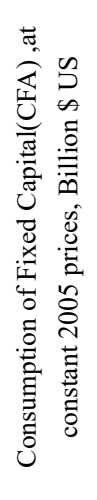 & 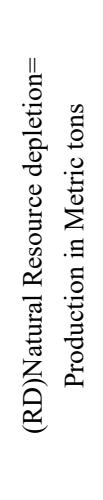 & 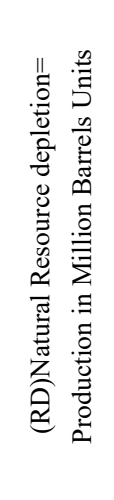 & 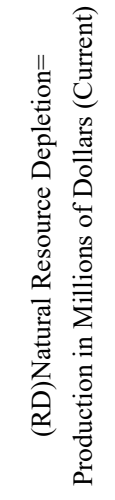 & 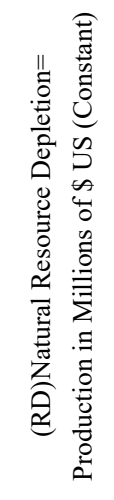 & 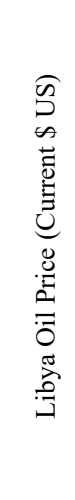 & 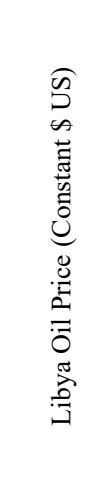 & 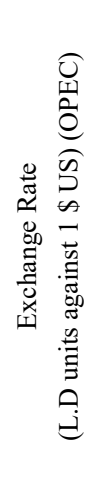 & 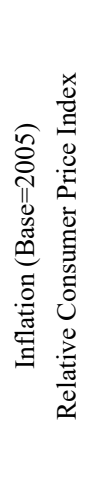 \\
\hline 1990 & 31.09 & 29.01 & 3.45 & 4.76 & 64.95 & 476.08 & 10141.0 & 13972 & 21.3 & 15.46 & 0.28 & 0.73 \\
\hline 1991 & 34.41 & 32.88 & 3.86 & 4.75 & 72.81 & 533.68 & 10140.0 & 12486 & 19.0 & 15.43 & 0.28 & 0.81 \\
\hline 1992 & 36.45 & 32.48 & 4.11 & 4.63 & 69.12 & 506.63 & 9575.3 & 10782 & 18.9 & 16.79 & 0.28 & 0.89 \\
\hline 1993 & 32.98 & 33.51 & 3.66 & 3.71 & 65.54 & 480.38 & 7686.1 & 7792 & 16.0 & 15.78 & 0.31 & 0.99 \\
\hline 1994 & 30.77 & 33.68 & 3.38 & 3.26 & 66.21 & 485.32 & 7425.4 & 7161.1 & 15.3 & 15.86 & 0.32 & 1.04 \\
\hline 1995 & 28.29 & 32.94 & 3.00 & 2.7 & 67.37 & 493.79 & 8345.1 & 7505.3 & 16.9 & 18.79 & 0.35 & 1.11 \\
\hline 1996 & 31.28 & 33.64 & 3.30 & 2.85 & 67.13 & 492.03 & 10037 & 8677.6 & 20.4 & 23.6 & 0.36 & 1.16 \\
\hline 1997 & 33.19 & 35.39 & 3.66 & 3.06 & 67.21 & 492.66 & 9212.8 & 7691.5 & 18.7 & 22.4 & 0.38 & 1.2 \\
\hline 1998 & 29.90 & 34.13 & 3.21 & 2.58 & 69.77 & 511.44 & 6290.8 & 5064.2 & 12.3 & 15.28 & 0.39 & 1.24 \\
\hline 1999 & 33.64 & 34.39 & 3.62 & 2.84 & 61.98 & 454.34 & 8178.0 & 6413.6 & 18.0 & 22.95 & 0.46 & 1.28 \\
\hline 2000 & 38.47 & 35.19 & 3.97 & 3.21 & 64.87 & 475.51 & 13267.0 & 10715 & 27.9 & 34.54 & 0.51 & 1.24 \\
\hline 2001 & 34.06 & 35.37 & 3.28 & 2.91 & 63.73 & 467.15 & 11118.0 & 9847.8 & 23.8 & 26.87 & 0.61 & 1.13 \\
\hline 2002 & 21.91 & 34.93 & 2.22 & 2.18 & 57.8 & 423.66 & 10253 & 10067 & 24.2 & 24.65 & 1.27 & 1.02 \\
\hline 2003 & 26.24 & 39.46 & 2.73 & 2.74 & 68.95 & 505.4 & 14404 & 14460 & 28.5 & 28.39 & 1.29 & 1.00 \\
\hline 2004 & 33.29 & 41.21 & 3.89 & 3.99 & 76.12 & 557.93 & 21146 & 21706 & 37.9 & 36.92 & 1.31 & 0.97 \\
\hline 2005 & 45.45 & 45.45 & 5.13 & 5.13 & 81.53 & 597.64 & 31495 & 31495 & 52.7 & 52.70 & 1.31 & 1.00 \\
\hline 2006 & 55.08 & 48.50 & 6.70 & 6.60 & 84.33 & 618.11 & 40189 & 39611 & 65.0 & 65.97 & 1.31 & 1.01 \\
\hline 2007 & 62.67 & 50.97 & 8.65 & 8.03 & 80.60 & 590.82 & 43065 & 39949 & 72.9 & 78.58 & 1.26 & 1.08 \\
\hline 2008 & 81.38 & 52.35 & 11.43 & 9.60 & 82.90 & 607.62 & 59389 & 49919 & 97.7 & 116.28 & 1.22 & 1.19 \\
\hline 2009 & 58.76 & 51.98 & 7.41 & 6.08 & 70.98 & 520.27 & 31513 & 25851 & 60.6 & 73.83 & 1.25 & 1.22 \\
\hline
\end{tabular}

Sources:

Gross Domestic Product (GDP at current price) - United Nations.2013.National Accounts Main Aggregates Database. Basic Data Selection. http://unstats.un.org/unsd/snaama/selbasicFast.asp.

Consumption of Fixed Assets (Capital) - The World Bank. 2013. World Development Indicators. http://databank.worldbank.org/data/views/variableselection/selectvariables.aspx?source=world-development-indi cators.

Production - UNdata. http://data.un.org/Data.aspx?d=EDATA\&f=cmID\%3aCR\%3btrID\%3a01

Exchange rate-OPEC-different years-annual statistical bulletin, http://www.opec.org/opec_web/en/publications/202.htm

Libyan oil price- OPEC- different years-annual statistical bulletin, http://www.opec.org/opec_web/en/publications/202.htm

Net Domestic Product $=$ GDP minus Consumption of Fixed Capital

Current Extraction $=$ Production .

For inflation, the year 2005 is a base year. 
Table 3. Calculations the second part of terms

\begin{tabular}{|c|c|c|c|c|c|}
\hline 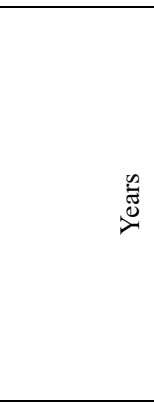 & 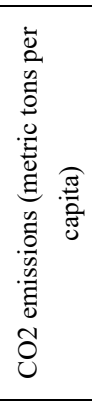 &  & 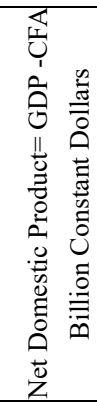 &  &  \\
\hline 1990 & 8.5 & 2.26 & 24.25 & 13.97 & 24.24 \\
\hline 1991 & 9.7 & 2.54 & 28.13 & 12.49 & 28.12 \\
\hline 1992 & 8.3 & 4.10 & 27.86 & 10.78 & 27.85 \\
\hline 1993 & 8.5 & 3.41 & 29.8 & 7.79 & 29.79 \\
\hline 1994 & 9.4 & 3.19 & 30.42 & 7.16 & 30.42 \\
\hline 1995 & 9.6 & 2.77 & 30.23 & 7.51 & 30.23 \\
\hline 1996 & 9.1 & 3.41 & 30.78 & 8.68 & 30.78 \\
\hline 1997 & 9.1 & 3.31 & 32.33 & 7.69 & 32.33 \\
\hline 1998 & 9.0 & 4.55 & 31.55 & 5.06 & 31.55 \\
\hline 1999 & 8.7 & 4.23 & 31.55 & 6.41 & 31.54 \\
\hline 2000 & 9.0 & 4.04 & 31.98 & 10.72 & 31.97 \\
\hline 2001 & 9.0 & 4.04 & 32.47 & 9.85 & 32.46 \\
\hline 2002 & 8.8 & 4.31 & 32.75 & 10.07 & 32.74 \\
\hline 2003 & 8.9 & 3.87 & 36.72 & 14.46 & 36.70 \\
\hline 2004 & 8.9 & 3.96 & 37.22 & 21.71 & 37.20 \\
\hline 2005 & 9.0 & 4.22 & 40.32 & 31.50 & 40.29 \\
\hline 2006 & 9.1 & 4.29 & 41.90 & 39.61 & 41.86 \\
\hline 2007 & 9.0 & 6.23 & 42.94 & 39.95 & 42.90 \\
\hline 2008 & 9.8 & 8.58 & 42.74 & 49.92 & 42.69 \\
\hline 2009 & 10.0 & 8.91 & 45.90 & 25.85 & 45.87 \\
\hline
\end{tabular}

Sources:

Average cost of barrel oil production, United States Energy Information Administration (EIA). Different Reports, $\mathrm{http}: / / \mathrm{www}$. eia.gov/finance/reports.cfm

Carbon Dioxide Emissions, metric tons/capita, World Bank. World Development Indicators.

http://databank.worldbank.org/data/views/variableselection/selectvariables.aspx?source=world-development-indi cators.

Production (metric tons, thousand), UN data, different years, http://data.un.org/Data.aspx?d=EDATA\&f $=$ cmID\%3aCR\%3btrID\%3a01

Libyan production cost per barrel (in dollars) represented by the Africa production cost since there is no Libya production cost per barrel data available.

\section{Results and Discussion}

As noted in Table 4, the smallest market value of depletion was $\$ 5.72$ billion in 1993 using the World Bank Method. The value of depletion increased to $\$ 46.24$ billion in 2008 . These values fluctuated during the first part of study and then increased from 2002 through the end of the study period. The results suggest that policy makers during this period did not place an emphasis on sustainability. It also appears that there were no plans or strategies to create a balance between the current and future generations.

For example, during the last nine years of the study, depletion increased sharply, and at the same time the price of crude oil more than doubled in comparison to the first ten years of study. In contrast, it would be expected that depletion would decrease, because of a financial surplus and thus create more savings for future generations during a period of rapidly rising prices. This is especially true given that there was not a sizeable increase in population and there were not any other significant competing development projects in Libya during this period. Considering 
the market value of depletion under the net price method, from 1990 to 2000 the market value fluctuates, because the amount of new oil discoveries are not treated consistently and because of the lack of a strategic plan for using the oil reserves. Conversely, the market value of depletion increases sharply from 2001 to 2009. Again, this fluctuation is due to the inconsistent consumption of oil reserves.

Table 4. Sustainable Development and Market value of Depletion using World Bank and Net Price Methods

\begin{tabular}{|c|c|c|c|c|c|}
\hline 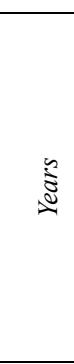 &  & 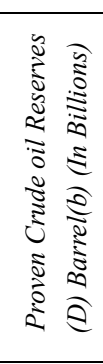 & 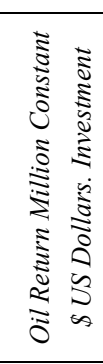 & 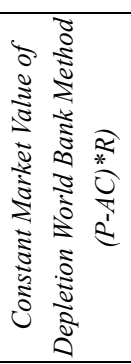 &  \\
\hline 1990 & 0.04 & 46.42 & 1460.2 & 11933 & $-1.15 \mathrm{E}+12$ \\
\hline 1991 & 0.03 & 44.27 & 1091.2 & 10429 & $-8.55 \mathrm{E}+11$ \\
\hline 1992 & 0.03 & 43.66 & 964.92 & 8146.2 & $-6.94 \mathrm{E}+11$ \\
\hline 1993 & 0.02 & 41.46 & 778.65 & 6107 & $-5.21 \mathrm{E}+11$ \\
\hline 1994 & 0.03 & 41.46 & 962.01 & 5719.6 & $-4.83 \mathrm{E}+11$ \\
\hline 1995 & 0.03 & 39.13 & 1014.2 & 6399.5 & $-5.01 \mathrm{E}+11$ \\
\hline 1996 & 0.04 & 39.13 & 1113.8 & 7422.7 & $-5.83 E+11$ \\
\hline 1997 & 0.04 & 36.00 & 1096.3 & 6556.2 & $-4.73 E+11$ \\
\hline 1998 & 0.05 & 36.00 & 1370.8 & 3557.3 & $-2.47 \mathrm{E}+11$ \\
\hline 1999 & 0.07 & 36.00 & 1767.4 & 5230.7 & $-4.09 \mathrm{E}+11$ \\
\hline 2000 & 0.07 & 29.50 & 1928.0 & 9463.4 & $-5.78 \mathrm{E}+11$ \\
\hline 2001 & 0.10 & 29.50 & 3214.6 & 8366.5 & $-5.20 \mathrm{E}+11$ \\
\hline 2002 & 0.31 & 29.50 & 10701 & 8307.6 & $-5.70 \mathrm{E}+11$ \\
\hline 2003 & 0.26 & 29.50 & 10437 & 12487 & $-7.16 \mathrm{E}+11$ \\
\hline 2004 & 0.66 & 29.50 & 27928 & 19380 & $-1.01 \mathrm{E}+12$ \\
\hline 2005 & 0.99 & 41.65 & 44966 & 28973 & $-1.99 \mathrm{E}+12$ \\
\hline 2006 & 1.18 & 41.46 & 56422 & 37034 & $-2.45 \mathrm{E}+12$ \\
\hline 2007 & 1.21 & 43.66 & 56985 & 36781 & $-2.68 \mathrm{E}+12$ \\
\hline 2008 & 1.51 & 46.27 & 66274 & 46237 & $-3.47 \mathrm{E}+12$ \\
\hline 2009 & 0.85 & 46.42 & 36362 & 22731 & $-2.01 \mathrm{E}+12$ \\
\hline
\end{tabular}

Sources:

Oil Revenue. Reports from the Central Bank of Libya, Economic Issues- different years, Research and statistics Department. http://www.cbl.gov.ly/eg/

Proven crude oil reserves, - OPEC - different years-annual statistical bulletin, http://www.opec.org/opec_web/en/publications/202.htm

Natural resource depletion represents by production since the amount of depletion equals the amount of production.

Libyan production cost of per barrel in dollars represents by the Africa production cost since Libya lies on the Africa, and there is no data represents Libya production cost of in dollars per barrel.

Libyan oil return represents an investment for Libyan economy since there is not any improving in the economic sectors, and there is no data indicated the Libyan investment.

Changing Libyan oil return from Libyan dinar to USA dollar

Changing units from metric tons to barrels multiply 7.33 with value of metric tonshttp://www.bp.com/conversionfactors.jsp

A simple (b) represents barrels of oil.

Calculate development sustainable by divide revenue (investment) on gross domestic product (Auty and Mikesell (1998)). 
In Table 3, the Environment Domestic Product (EDP), which is equal to the Gross Domestic Product minus depreciation of natural resources or consumption of fixed capital, indicates EDP can be used to determine depreciation. The EDP increased sharply from the beginning of the study from $\$ 24.24$ billion in 1991 until reaching $\$ 45.87$ billion in 2009 in constant dollars. Again, it can be inferred that policy makers did not consider the depletion of oil resources and the environment in their planning process or at least did not place a high level of concern on this issue.

Carbon dioxide emissions are another indication of the presence or absence of sustainability. In Table 3, the ratio of carbon dioxide ranges from a minimum ratio of 8.50 in 1990 to 10.00 in 2009. This range is much higher than compared to the Middle East and North Africa as a whole and further confirms the low interest in sustainability in Libya.

\section{Conclusions}

Oil is the primary raw material underlying potential future economic growth in the Libyan economy (Danvers, 2016). All Libyans, current and future generations, have the right to the potential benefits of exploiting this resource. The previous government was unconcerned with the depletion of or the sustainability of its oil resources. It was also clear that the ratio of $\mathrm{CO}_{2}$ emissions is much higher compared to other countries in the Middle East and North Africa. This indicates there was relatively little interest in the sustainable development of the Libyan economy. In Table 4, development sustainability equals investment divided by GDP. This provides another indication of the low level of sustainable development in Libya over the period of analysis. Hence, it is important that government develop and implement new plans and strategies for achieving sustainability and the maintenance of oil resources. Since the oil resource is the key source of national income of Libya, the new government should place a higher priority on sustainability, while working to diversify their economy. Moreover, the environment domestic product (EDP) is characterized by very high values, which is also an indication of the need to maintain the environment and decrease the release of pollutants into the environment.

It should be noted that most developing countries, which depend on oil as their primary source of national income face different issues from other countries in achieving sustainable development. Developing oil producing countries may face increased depletion, and the increased costs of reducing depletion, among others (Bazilian et al. 2013). Given the current political strife in Libya, the country has an almost total lack of effective strategies for achieving the sustainable development of its oil resources for the benefit of current and future generations. However, the previously analysis does provide some important insights into this question for Libya once the current conflict is resolved and for other oil producing countries as they plan for the future.

\section{References}

Ali, N. (2009). Sustainability of petroleum and environmental control in the Malaysian petroleum law. Malaysia: Kolej University Islam

Al-Majed, A., Adebayo, A., \& Hossain, M. (2012). A sustainable approach to controlling oil spills. Journal of Environmental Management, 113, 213-227. http://dx.doi.org/10.1016/j.jenvman.2012.07.034

Auty, M., \& Mikesell, R. (1998). Sustainable development in mineral economics. United States: Oxford: Clarendon Press Inc.

Bardi, U. (2005). The mineral economy: a model for the shape of oil production curves. Energy Policy, 33, 53-61. http://dx.doi: 10.1016/S0301-4215(03)00197-6

Bazilian, M., Onyeji, I., Aqrawi, P., Sovacool, B. K., Ofori, E., Kammen, D. M., \& Graaf, T. V. (2013). Oil, energy poverty and resource dependence in West Africa. Journal of Natural Resources Law, 31(1), 33-53. http://dx.doi.org/10.1080/02646811.2013.11435316

Berke, P., \& Conory, M. (2000). Are we planning for sustainable development? Journal of the American Planning Association, 66(1), 21-33. http://dx.doi:10.1080/01944360008976081

Cavagnaro, E., \& Curie, G. (2012). The three levels of sustainability. United Kingdom: Greenleaf publishing Limited.

CIA. (2013). The world fact book 2013: Libya. Retrieved May 13, 2013, from https://www.cia.gov/library/ publications/the-world-factbook/geos/ly.html

Cooper, J. P., \& Vargas, C. M. (2008). Sustainable development in crisis conditions, challenges of war, terrorism, and civil disorder. United States: Rowman and Littlefield publishers, Inc. 
Danvers, W. (2016). Next steps in Libya: Economic and government stabilization in the face of political and security challenges. Center for American Progress. Retrieved from https://cdn.americanprogress.org/ wp-content/uploads/2016/07/26074652/2LibyaStabilization-report.pdf

El Serafy, S. (1989). The proper calculation of income from depletable natural resources. In Y. J. Aahmed, S. El-Serafy, \& E. Lutz (Eds.), Environmental accounting for sustainable development. World Bank, Washington, DC: 10-18.

Eljabri, A., \& Gallagher, C. (2012). Developing integrated remote sensing and GIS procedures for oil spills monitoring at Libyan coast. 2nd International Conference on Environment and Bio Science, IPCBEE, 44, IACSIT Press, Singapore.

Energy Information Administration. (1984). The petroleum resources of Libya, Algeria, and Egypt report, U.S., Washington, D.C.20585.

Energy Information Administration. (n. d. ). Different Reports. Average cost of barrel oil production. United States. Retrieved from http://www.eia.gov/finance/reports.cfm

Goldin, I., \& Winters, L. A. (1995). The economics of sustainable development. First Published, United Kingdom: Cambridge University Press.

Green, B. D., \& Blatner, K. A. (2015). Sustainability and depletion accounting for non-renewable resources: the case of copper in Chile. Environment and Natural Resources Research, 5(4), 16-29. Http://dx.doi:10.5539/ enrr.v5n4p16)

Hotelling, H. (1931). The economics of exhaustible resources. Journal of Political Economy, 39(2), 137-75.

Kasemir, B., Jager, J., Jaeger, C. C., \& Gardener, T. M. (2003). Public participation in sustainability science: A handbook. United Kingdom: Cambridge University press.

Mikesell, R. (1997). Explaining the resource curse, with special reference to mineral exporting countries. Resources Policy, 23(4), 191-199.

Naimi, A. (2011). Sustainability issues in the petroleum refining industry: A case study of shell. Otago Management Graduate Review, 9, 93-113.

Neumayer, E. (2000). Resource accounting in measures of unsustainability - challenging the world bank's conclusions. Environmental Resource Economics, 15, 257-278. http:// dx.doi: 10.1023/A:1008304812545

OPEC. (n.d.). Different annual statistical bulletin, crude oil price. Retrieved from http://www.opec.org/ opec_web/en/publications/202.htm.

Peet, J. (1992). Energy and the ecological economics of sustainability. Washington, D.C.: Island Press.

Prior T., Giurco, D., Mudd, G., Mason, L. \& Behrisc, L. (2007). Resource depletion, peak minerals and the implications for sustainable resource management. IUCN, www.iucn.org, Switzerland.

Prugh, T., Costanza, R., \& Daly, H. (2000). The local politics of global sustainability. Washington, D.C.: Island Press.

Repetto, W., Magrath, W., Wells, M., \& Rossini, F. (1989). Wasting assets, natural resources in the national income accounts. World Resources Institute, Washington, DC.

Rubio, M. (2004). The capital gains from trade are not enough: evidence from the environmental accounts of Venezuela and Mexico. Journal of Environmental Economics and Management, 48, $1175-1191$. http://dx.doi.org/10.1016/j.jeem.2004.02.002

Santopietro, G. (1998). Alternative Methods for Estimating Resource Rent and Depletion Cost: The Case of Argentina's YPF. Resources Policy, 24(1), 39-48.

Schneider, J., Campbell, D., Vargo, C., \& Hall, R. (2011). An Analysis of reported sustainability-related efforts in the petroleum refinery industry. Greenleaf publishing. Journal of Corporate Citizenship, 44, 69-84.

The Central Bank of Libya. (n. d. ). Economic issues - different years. Research and statistics Department. Retrieved from http://www.cbl.gov.ly/eg/

Thompson, H. (2012). Economic growth with a nonrenewable resource. The Journal of Energy and Development. $36(1), 35-43$.

Transparency International. (2012). Corruption perceptions index 2012: Full table and rankings. Retrieved from http://www.transparency.org/cpi2012/results 
United Nations. (1987). Report of the world commission on environment and development. Retrieved from http://www.un-documents.net/our-common-future.pdf

United Nations. (2013). Data. Retrieved fom http://data.un.org/Data.aspx?d=EDATA\&f=cmID\%3aCR\% 3btrID\%3a161

United Nations. (2013). National accounts main aggregates database: Basic data selection. Retrieved from http://unstats.un.org/unsd/snaama/selbasicFast.asp.

Wallace, J., \& Wilkinson, B. (2004). Doing business with Libya. UK and US. London: Kogan Page Limited Global Market Briefings, Second Edition.

Weaver, L. J. (2003). Sustainable development in the petroleum sector. In A. Breadbrook, \& R. Ottinger (Eds.), Energy law and sustainable development. IUCN, Environmental Policy and Law Paper No.47, The World Conservation Union.

World Bank. (2013). Libya. http://data.worldbank.org/country/libya

World Bank. (2013). Population, total. Retrieved from http://data.worldbank.org/indicator/SP.POP.TOTL

World Bank. (2013). World development indicators. Retrieved from http://databank.worldbank.org/data/views/ variableselection/selectvariables.aspx? source=world-development-indicators.

World Bank. (2015). Adjusted savings: natural resources depletion (\% of GNI). Retrieved from http://data.worldbank.org/indicator/NY.ADJ.DRES.GN.ZS

\section{Copyrights}

Copyright for this article is retained by the author(s), with first publication rights granted to the journal.

This is an open-access article distributed under the terms and conditions of the Creative Commons Attribution license (http://creativecommons.org/licenses/by/4.0/). 